MIMBAR

JURNAL PENELITIAN SOSIAL DAN POLITIK

\title{
ANALISIS PENERAPAN PRINSIP-PRINSIP GOOD GOVERNANCE DALAM PELAYANAN PERIZINAN
}

(Studi di Dinas Penanaman Modal dan Perizinan Terpadu Satu Pintu Provinsi Bengkulu)

\author{
Oleh: \\ Mulyadi $^{*}$, Romdana ${ }^{2}$ \\ "Email Korespondensi : $\underline{\text { Stia.mulyadi@gmail.com }}$
}

\begin{abstract}
ABSTRAKS
Penerapan prinsip-prinsip good governance pada pelayanan perizinan sangat penting karena untuk menjaga standar kualitas pelayanan perizinan yang diberikan oleh DPMPTSP Provinsi Bengkulu, Tujuan penelitian untuk mengetahui apakah prinsip-prinsip good governance telah diterapkan dengan baik pada pelayanan perizinan DPMPTSP Provinsi Bengkulu. Pendekatan dalam penelitian ini adalah penelitian deskriptif kualitatif. Hasil penelitian menemukan bahwa penerapan prinsip-prinsip good governance pada pelayanan perizinan di DPMPTSP Provinsi Bengkulu diterapkan dengan baik, sebagaimana dibuktikan dari hasil penelitian : 1) Transparansi pelayanan perizinan sudah baik terlihat bagaimana informasi pelayanan yang disediakan oleh DPMPTSP Provinsi Bengkulu bagi masyarakat yang akan mengakses pelayanan perizinan, 2) Resposivitas sudah diterapkan dengan baik terlihat bagaimana daya tanggap yang diberikan oleh aparatur pelayanan kepada masyarakat pengguna pelayanan yang mengalami kesulitan pendaftaran, 3) efektivitas dan efisiensi diterapkan dengan baik dilihat dari ketersediaan sumber daya yang layak, adanya monitoring dan evaluasi setiap 2 kali setahun serta adanya pembagian tugas pokok dan fungsi yang jelas dari atasan.
\end{abstract}

Kata Kunci : Good Governance, Pelayanan Publik, Bengkulu

${ }^{1}$ Dosen Sekolah Tinggi Ilmu Administrasi (STIA) Bengkulu

${ }^{2}$ Dosen Sekolah Tinggi Ilmu Administrasi (STIA) Bengkulu 
MIMBAR

JURNAL PENELITIAN SOSIAL DAN POLITIK

\section{Desember $2018 \quad$ ISSN : 2252-5270 \& E-ISSN : 2620-6056}

Volume 7 No. 2

\section{A. Pendahuluan}

Untuk menghadapi berbagai tuntutan publik, salah satu prasyarat yang perlu dikembangkan adalah komitmen yang tinggi untuk menerapkan nilai prinsip-prinsip "Good Governance" dalam penuangan mewujudkan cita-cita dan tujuan bangsa Indonesia yang bersih dan bebas dari Korupsi Kolusi Dan Nepotisme (KKN). Sebagaimana diamanatkan dalam Undangundang Nomor 28 Tahun 1999 dalam Mustafa (2013:199-200), tentang penyelenggaraan Negara yang Bersih dan Bebas dari Korupsi, Kolusi Dan Nepotisme (KKN), meliputi : asas kepastian hukum, asas tertib penyelenggaraan negara, asas kepentingan umum, asas keterbukaan, asas proporsionalitas, asas profesionalitas dan asas akuntanbilitas.

Pelayanan publik merupakan bagian dari pemerintahan yang baik (good governance) dengan cara memberikan layanan baik kepada masyarakat. Prinsip good governance bisa terwujud apabila pemerintahan diselenggarakan secara transparan, responsif, partisipatif, taat hukum (rule of law), sesuai konsensus, non diskriminasi, akuntabel, serta memiliki visi yang strategis. Menurut Hardiyansyah (2013:143) bahwa pelayanan publik (public service) oleh birokrasi publik merupakan salah satu perwujudan dari fungsi aparatur negara sebagai abdi masyarakat disamping sebagai abdi negara. Pelayanan publik (public service) oleh birokrasi publik dimaksudkan untuk mensejahterakan masyarakat (welfare state).

Pelayanan masyarakat bisa dikatakan baik bila masyarakat dapat dengan mudah mendapatkan pelayanan tidak melalui prosedur yang panjang, biaya murah, waktu cepat dan hampir tidak ada keluhan yang diberikan kepadanya. Kondisi tersebut dapat terwujud apabila organisasi publik didukung oleh kualitas sumber daya manusia yang mumpuni baik itu dari segi kualitas atau kuantitas, disamping itu juga adanya sumber daya peralatan dan sumber daya keuangan yang memadai. Menurut Sujardi (2009:7), penyelenggaraan pelayanan publik merupakan upaya negara untuk memenuhi kebutuhan dasar dan hak-hak sipil setiap warga negara atas barang, jasa, dan pelayanan administrasi yang disediakan oleh penyelenggara pelayanan publik. Sedangkan menurut Pasal 1 ayat 4 Undang-undang No. 25 Tahun 2009, penyelenggara pelayanan publik yaitu setiap instansi /pemerintah, korporasi, dan lembaga independen yang dibentuk berdasarkan undang-undang untuk memberikan pelayanan publik, yang transparansi, responsivitas, akuntanbilitas, efektif dan efisiensi guna memberikan pelayanan yang berkualitas kepada masyarakat. Namun, menurut Achmad Hidayat Rahadian (2009), hingga saat ini pelayanan publik di Indonesia seringkali dicirikan oleh inefisiensi yang tinggi, prosedur yang berbelit-belit, serta tidak adanya kepastian waktu dan biaya yang diperlukan dalam penyelenggaraan layanan.

Lebih dari itu, penyelenggaraan pelayanan publik masih sangat dipengaruhi oleh subjektivitas, baik yang dimiliki oleh penyelenggara atau para pengguna. Oleh karena itu sebaiknya pemerintah daerah memberikan prioritas pada reformasi birokrasi sebagai bagian dari tindakan yang kongkrit dalam membangun good governance. Bahkan lebih konkrit lagi, perbaikan praktek penyelenggaraan pelayanan publik semestinya menjadi agenda awal dari reformasi birokrasi. Penyelenggaraan pelayanan publik menjadi core business dari birokrasi pemerintah daerah. Dengan berhasil memperbaiki penyelenggaraan pelayanan publik menjadi transparan, responsif dan efektif serta efisien, maka pemerintah daerah bukan hanya dapat memperbaiki kinerja birokrasi tetapi juga membangun good local governance.

Dinas Penanaman Modal dan Perizinan Terpadu Satu Pintu (DPMPTSP) Provinsi Bengkulu memiliki tugas dan fungsi sebagai pelayan publik dibidang perizinan oleh karena itu sangat peting dalam menerapan prinsip transparansi, responsivitas, efektivitas dan efisiensi.

Berdasarkan pemaparan diatas, DPMPTSP Provinsi Bengkulu memiliki peran yang sangat penting dalam pelayanan publik khususnya pelayanan perizinan, sehingga diharapkan aparatur pemberi layanan dapat berkerja secara profesional, bertanggung jawab, transparan. Dengan demikian akan menghasilkan pelayanan yang berkualitas sesuai dengan prinsipprinsip good governace. Dari pengamatan 


\section{MIMBAR}

JURNAL PENELITIAN SOSIAL DAN POLITIK

penulis DPMPTSP Provinsi Bengkulu dalam memberikan pelayanan perizinan menggunakan prosedur pelayanan harus dilengkapi izin sehingga mudah dimengerti dan diakses masyarakat dengan menggunakan waktu pelayanan yang relative singkat, sesuai dengan prinsipprinsip good governance dalam pelayanan publik.

jadi sangat penting penerapan prinsipprinsip good governance pada pelayanan perizinan, supaya terciptanya pelayanan yang transparan, respon, dan efisiensi sesuai dengan tuntutan masyarakat. Maka diharapkan aparatur pemerintah yang menyediakan pelayanan pada DPMPTSP Provinsi Bengkulu menerapkan prinsipprinsip good governance, supaya tercipta pelayanan berkualitas yang akan berpengaruh terhadap kepuasan masyarakat Provinsi Bengkulu. Dari uraian masalah diatas maka fokus artikel ini yaitu penerapan Prinsip- Prinsip Good Governance pada Pelayanan Perizinan di DPMPTSP Provinsi Bengkulu"

\section{B. Metode Penelitian}

Penelitian menggunakan metode kualitatif dengan pendekatan deskriptif kualitatif. Teknik pengumpulan data dilakukan dengan metode wawancara, observasi, dan dokumentasi.

Adapun fokus penelitian yaitu menganalisis penerapan prinsip-prinsip good governance dalam pelayanan perizinan di DPMPTSP Provinsi Bengkulu dengan teknik analisis data dilakukan melalui tiga tahap yaitu : pengumpulan data (data collection), penyajian data (data display), verifikasi data (data verification), dan penarikan kesimpulan (drawing conclusion).

\section{Hasil Penelitian}

Penerapan prinsip-prinsip good governance di DPMPTSP Provinsi Bengkulu akan berjalan dengan baik apabila masyarakat yang mengakses pelayanan merasa puasa dengan hasil pelayanan di DPMPTSP Provinsi Bengkulu, berikut ini beberapa prinsip good governance dalam penelitian ini :

\section{a. Transparansi}

Transparansi (Transparency), yaitu menciptakan kepercayaan timbal balik antara pemerintah dan masyarakat melalui penyediaan informasi dan menjamin kemudahan dalam memperoleh informasi yang akurat dan memadai. dengan indikator sebagai berikut : 1) Tersedianya informasi yang memadai pada setiap proses penyelenggaraan pelayanan perizinan di DPMPTSP Provinsi Bengkulu Bengkulu. 2) Kemudahan dalam mengakses informasi yang dapat diperoleh dan tepat waktu. 3) Tersedianya papan pengumuman atau papan informasi tentang tata cara pelayanan perizinan DPMPTSP Provinsi Bengkulu. Sesuai wawancara dengan informan pada tanggal (3 September 2018) bahwa ;

"Informasi yang disediakan dan berikan kepada masyarakat untuk mengakses perizinan sudah baik karena sudah secara detail baik dari mulai tahap pelayanan sampai dengan administrasinya."

Tersedianya informasi baik berbentuk web maupun informasi dari papan informasi di kantor telah disediakan oleh DPMPTSP Provinsi Bengkulu sehingga masyarakat yang mengurus perizinan tidak mengalami kebingugan mengenai tata cara pendaftaran dan semua memudahkan pengguna pelayanan. Sesuai dengan wawancara Tanggal (3 September 2018), bahwa ;

"Sebagai pengguna saya sangat terasa dibantu dengan informasi yang tersedia di Web DPMPTSP Provinsi Bengkulu yang mana disana telah diinformasikan dengan jelas tata cara pendaftaran dan pembayaran. Di web juga sudah tersedia untuk mengakses pendaftaran online sehingga kita tidak perlu datang langsung bisa daftar online."

DPMPTSP Provinsi Bengkulu sudah berkomitmen memberikan pelayanan yang prima sesuai dengan prinsip good governance. Karena masyarakat merupakan pelanggan utama dalam pelayanan yang kami berikan. Semakin baiknya pelayanan yang kami berikan, maka semakin baik pula penilaian masyarakat provinsi Bengkulu.

\section{b. Responsivitas}

Responsivitas (responsiveness), yaitu aparatur pemerintah harus cepat tanggap dalam menyelesaikan tuntutan masyarakat dalam pelayanan publik (Triyanto, 2017), Meliputi indikator sebagai berikut : 1) Tersedianya layanan pengaduan, baik berupa criss center, Unit Pelayanan Masyarakat 
MIMBAR

JURNAL PENELITIAN SOSIAL DAN POLITIK Desember $2018 \quad$ ISSN : 2252-5270 \& E-ISSN : 2620-6056 Volume 7 No. 2

(UPM), kotak saran, dan surat pembaca yang mudah diakses masyarakat. 2) Adanya prosedur pelayanan pengaduan masyarakat. 3) Tersediannya standar pelayanan minimalis di DPMPTSP Provinsi Bengkulu. Sesuai dengan hasil wawancara tanggal (4 September 2018) bahwa ;

"DPMPTSP Provinsi Bengkulu telah menyediakan layanan pengaduan baik yang ada di web maupun yang disediakan di kantor secara langsung, prosedurnya juga sudah jelas ada di papan informasi dan di web DPMPTSP Provinsi Bengkulu sehingga memudahkan masyarakat sebagai pengguna pelayanan."

Tersedianya informasi layanan pengaduan yang ada pada papan informasi di DPMPTSP Provinsi Bengkulu dan di web resmi yang dimiliki DPMPTSP sehingga masyarakat yang mengalami permasalahan tidak binggung untuk mengadu kepada aparatur pelayanan.

Selain itu aparatur DPMPTSP Provinsi Bengkulu memiliki standar pelayanan minimal sehingga mutu pelayanan juga terjaga, dan memiliki aturan yang jelas. Sesuai dengan wawancara Tanggal (4 September 2018), bahwa ;

"Kami menjaga mutu pelayanan yang ada di DPMPTSP Provinsi Bengkulu dengan menerbitkan SPM sehingga pelayanan harus ada standar minimal, dan kami menempelnya pada papan pelayanan sehingga masyarakat dapat komplain apabila pelayanan kami di bawah SPM yang telah kami tentukan ."

Hasil penelitian di DPMPTSP Provinsi Bengkulu mengenai responsivitas pelayanan sudah diterapkan dengan baik, karena aparatur pelayanan merespon setiap pengaduan masyarakat dengan memberikan nomor pengaduan dan kotak pengaduan yang ada di kantor. Selain itu DPMPTSP Provinsi Bengkulu juga telah menyusun SPM sehingga mutu pelayanan yang diberikan terjamin.

\section{c. Efektivitas dan Efisiensi}

Efektivitas dan Efesiensi (Effectiveness and Efficiency), yaitu setiap proses kegiatan dan kelembagaan diarahkan untuk menghasilkan sesuatu yang benar-benar sesuai dengan kebutuhan melalui pemanfaatan yang sebaik-baiknya dari berbagai sumber yang tersedia. Meliputi indikator sebagai berikut : 1) Terlaksananya administrasi penyelenggaraan pelayanan yang berkualitas, tepat sasaran dan didukung dengan sumber daya yang optimal, 2) Adanya monitoring dan evaluasi untuk memperbaiki kualitas pelayanan yang ada. 3) Tidak adanya tumpang tindih kinerja pegawai dalam memberikan pelayanan.

Sesuai dengan hasil wawancara tanggal (5 September 2018) bahwa ;

"Sumber daya manusia yang dimiliki DPMPTSP Provinsi Bengkulu untuk mendukung terlaksananya pelayanan yang prima sudah tersedia dengan baik, yaitu dengan adanya aparatur muda yang ditempatkan pada bagian pelayanan sehingga pelayanan dapat cepat dan tepat, dengan dilayani aparatur muda diharapkan dapat meminimalisir human error sehingga masyarakat sebagai pengguna pelayanan tidak merasa dirugikan."

Selain sumber daya manusia sebagai pendukung pelayanan yang berkualitas juga perlunya monitoring dan evaluasi yang dilakukan oleh DPMPTSP Provinsi Bengkulu, dengan adanya monev diharapkan dapat meningkatan kualitas pelayanan dengan melakukan perbaikanperbaikan. Sesuai hasil wawancara tanggal (5 September 2018) bahwa ;

"DPMPTSP Provinsi Bengkulu selalu melakukan monev setiap 6 bulan sekali untuk menganalisis kekurangan pada pelayanan yang kami berikan, dengan adanya monev ini kami berharap dapat memperbaiki kualitas pelayanan sehingga masyarakat merasa nyaman dan puas ketika menggunakan pelayanan disini."

Kemudian perlu adanya pembagian tugas dan wewenang yang jelas sehingga tidak adanya tumpang tindih tugas bagi aparatur pelayanan di DPMPTSP Provinsi Bengkulu. Sesuai dengan wawancara Tanggal (6 September 2018), bahwa ;

"Dalam pelaksanaan tugas pelayanan kami telah dibagi tugas masing-masing sesuai dengan tugas pokok dan fungsi kami, sehingga kerja kami jelas tidak adanya tumpang tindih, seperti saya bagian pelayanan perizinan penelitian sama akan melayani itu, yang bagian pelayanan perizinan pendirian usaha, danefektivitas 
MIMBAR

JURNAL PENELITIAN SOSIAL DAN POLITIK

bagian pengaduan sehingga sudah jelas.”

Hasil penelitian mengenai efetivitas dan efisiensi di DPMPTSP Provinsi Bengkulu dalam memberikan pelayanan perizinan bahwa telah diterapkan dengan baik, karena ketersediaan sumberdaya yang memiliki kompetensi dalam menunjang pelayanan perizinan di DPMPTSP Provinsi Bengkulu sudah baik, selain itu juga dilakukan monitoring dan evaluasi pelayanan untuk menjaga kualitas pelayanan di DPMPTSP Provinsi Bengkulu. Kemudian dalam pembagian tugas, pokok dan fungsi aparatur juga jelas sehingga berdampak pada baiknya kualitas pelayanan.

\section{Pembahasan}

Pengertian good governance menurut Lembaga Administrasi Negara Republik Indonesia (LAN-RI) dalam Sujardi, (2009:20), adalah: "Pengelolaan pemerintahan yang baik dan bertanggung jawab". Lebih lanjut dikemukakan oleh Dwiyanto (2008:20), good governance adalah sebagai gerakan yang didorong oleh kepentingan berbagai lembaga donor dan keuangan internasional untuk memperkuat institusi yang ada di negara dunia ketiga dalam melaksanakan berbagai kegiatan yang dibiayai oleh berbagai lembaga itu. Mereka menilai bahwa kegagalan-kegagalan proyek mereka disebabkan karena lemahnya institusi pelaksana di negara-negara dunia ketiga yang disebabkan oleh praktik bad governance seperti tidak transparan, rendahnya kualitas pelayanan terhadap masyarakat, rendahnya daya tanggap terhadap kebutuhan masyarakat, diskriminasi terhadap stakeholder yang berbeda, dan efisiensi.

Ada 3 indikator yang digunakan untuk mengukur penerapan prinsip-prinsip good governance, dengan menggunakan teori UNDP dalam Serdamayanti (2004:5) yaitu : 1.) Transparansi (keterbukaan) 2). Efektivitas dan efesiensi 3). Responsivitas (daya tanggap). Dari ketiga indikator tersebut dalam implementasinya secara langsung dapat dirasakan oleh masyarakat pada pelayanan pembayaran pajak kendaraan bermotor di DPMPTSP Provinsi Bengkulu.

Apabila dalam pelayanan perizinan menerapkan ketiga indikator tersebut dengan baik, maka akan tercipta pelayanan yang berkualitas yang kemudian akan berdampak pada kepuasan masyarakat. Kemudian peneliti mengambil beberapa informan yang dijadikan informan dengan tujuan untuk mengetahui penerapan prinsip-prinsip good governance pada pelayanan perizinan di DPMPTSP Provinsi Bengkulu. Berdasarkan hasil penelitian bahwa transparansi yang ada pada pelayanan perizininan DPMPTSP Provinsi Bengkulu telah diterapkan dengan baik terilihat dari tersedianya informasi secara rinci baik pada web, ataupun informasi pada papan informasi yang disediakan di DPMPTSP Provinsi Bengkulu sehingga masyarakat yang mengurus perizinan tidak mengalami kebingungan mengenai tata cara pendaftataran sampai dengan pembayaran karena semua proses memudahkan pengguna pelayanan.

Indikator responsivitas aparatur pelayanan yang ada di DPMPTSP Provinsi Bengkulu telah diterapkan dengan baik. Dapat dilihat dari daya tanggap pada pengaduan pelayanan apabila masyarakat mengalami kesulitan atau permasalahan dalam mengakses pelayanan, DPMPTSP Provinsi Bengkulu menyediakan layanan itu di web maupun di kantor sehingga pelayanan dapat diakses dimana saja.

Efektivitas dan efesiensi pelayanan perizinan di DPMPTSP Provinsi Bengkulu telah diterapkan dengan baik. Dilihat dari ketersediaan sumberdaya yang memiliki kompetensi dalam menunjang pelayanan perizinan di DPMPTSP Provinsi Bengkulu, selain itu dilakukannya monitoring dan evaluasi pelayanan untuk menjaga kualitas pelayanan di DPMPTSP Provinsi Bengkulu selama 6 bulan sekali, kemudian dalam pembagian tugas, pokok dan fungsi aparatur sudah jelas, sehingga tidak tumpang tindih wewenang yang akan mengganggu pelayanan yang diberikan.

\section{E. Kesimpulan dan Saran}

\section{Kesimpulan}

Mengenai penerapan prinsip-prinsip good governance pada pelayanan perizinan di DPMPTSP Provinsi Bengkulu telah terapkan dengan baik, sebagaimana dibuktikan dari hasil penelitian : 1) Transparansi pelayanan perizinan sudah baik terlihat bagaimana informasi pelayanan yang disediakan oleh DPMPTSP Provinsi Bengkulu bagi masyarakat yang akan 
mengakses pelayanan perizinan, 2) Resposivitas sudah diterapkan dengan baik terlihat bagaimana daya tanggap yang diberikan oleh apratur pelayanan kepada masyarakat pengguna pelayanan yang mengalami kesulitan pendaftaran, 3) efektivitas dan efesiensi diterapkan dengan baik dilihat dari ketersediaan sumber daya yang mumpuni, adanya monitoring dan evaluasi setiap 2 kali setahun serta adanya pembagian tugas pokok dan fungsi yang jelas dari atasan.

\section{Saran}

Saran yang dapat diberikan atas permasalahan penerapan prinsip good governance pada pelayanan perizinan di DPMPTSP Provinsi Bengkulu berikut :

1) Memperbaiki website DPMPTSP supaya kedepan pemohon perizinan yang berbayar dapat melakukan pembayaran dengan online.

2) Memperbaiki masalah penyelesaian waktu pelayanan, dengan 1 hari waktu pelayanan.

3) Segera melakukan kerjasama dengan instansi terkait dalam pengurusan perizinan sehingga pelayanan perizinan dapat terintegrasi dalam satu kali pendaftaran.

\section{DAFTAR PUSTAKA}

Sumber dari Buku :

Atep, Adtya, Barata, 2004, Dasar-dasar Pelayanan Prima, Jakarta : PT. Elex Media Komputindo.

Dwiyanto, Agus, 2008. Mewujudkan Good Governance Melalui Pelayanan Publik, Yogyakarta: Gadjah Mada University Press.

Dwiyanto, Agustus.,dkk, 2006. Reformasi Birokrasi Publik di Indonesia, Yogyakarta: Gadjah Mada University Press.

Dwiyanto, Agus, 2011. Mengembalikan Kepercayaan Publik Melalui Reformasi Birokrasi, Jakarta : PT Gramedia Pustaka Utama.

Hardiyansyah, 2011, Kualitas Pelayanan Publik, Yogyakarta: Gava Media.

Hasibuan, Malayu S.P, 2003, Organisasi Dan Motivasi, Jakarta: PT Bumi Aksara.

Kumorotomo, Wahyudi dkk. 2009.
Governance Reform di Indonesia. Yogyakarta: Gava media dan MAPUGM.

Kurniawan, Agung, 2005, Transformasi Pelayanan Publik, Yogyakarta: Pembaruan.

Moenir. 2010. Manajemen Pelayanan Umum Di Indonesia, Jakarta: PT Bumi Askara. Mustafa, Dilly. 2013. Birokrasi Pemerintahan, Bandung: ALFABETA, cv Pasalong, Harbani. 2012. Metode Penelian Administrasi Publik, Bandung: ALFABETA, cv

Sedarmayanti, Hj. 2004. Good Governance (kepemerintahan yang baik), Bandung: Mandar Maju Sudijono,

Sugiyono. 2012. Metode Penelitian Kuantitatif Kualitatif Dan R\&D. Bandung: ALFABETA, cv

Surjadi, H. 2009. Pengembangan Kinerja Pelayanan Publik. Bandung: rafika ADITAMA.

Thoha, Miftah.2010. Ilmu Administrasi Publik Kontemporer. Jakarta: Kencana Prenada Media Group. Thoha, Miftah. 2011.Birokrasi Dan Politik Di Indonesia, Jakarta : Raja Grafindo Persada.

Triyanto, D. (2017). ANALISIS KINERJA ORGANISASI DALAM MEWUJUDKAN PELAYANAN PRIMA KEPADA MASYARAKAT (Studi Pada Kantor Badan Pelayanan Perizinan Terpadu Kota Semarang). MIMBAR: Jurnal Penelitian Sosial Dan Politik, 6(4). Retrieved from https://journals.unihaz.ac.id/index.php/ mimbar

\section{Sumber Non Buku :}

UU No 25 Tahun 2009 tentang Pelayanan Publik.

Web :

http://www.artikelilmiah.tk/2012/04/pengerti an-governance.html. diakses pada tanggal 22 November 2018.

http://lawyersinbali.wordpress.com/2011/04 127/pengertian-good-governancel diakses tanggal 22 November 2018. 